University of Nebraska - Lincoln

DigitalCommons@University of Nebraska - Lincoln

USDA National Wildlife Research Center - Staff Publications
U.S. Department of Agriculture: Animal and Plant Health Inspection Service

March 2004

\title{
Determination of Acetaminophen Residues in Whole Body Brown Treesnakes
}

Thomas M. Primus

USDA/APHIS/WS/National Wildlife Research Center

Dennis J. Kohler

USDA/APHIS/WS/National Wildlife Research Center, dennis.kohler@aphis.usda.gov

Carol A. Furcolow

USDA/APHIS/WS/National Wildlife Research Center

Margaret J. Goodall

USDA/APHIS/WS/National Wildlife Research Center

John J. Johnston

USDA/APHIS/WS/National Wildlife Research Center

See next page for additional authors

Follow this and additional works at: https://digitalcommons.unl.edu/icwdm_usdanwrc

Part of the Environmental Sciences Commons

Primus, Thomas M.; Kohler, Dennis J.; Furcolow, Carol A.; Goodall, Margaret J.; Johnston, John J.; and Savarie, Peter J., "Determination of Acetaminophen Residues in Whole Body Brown Treesnakes" (2004). USDA National Wildlife Research Center - Staff Publications. 379.

https://digitalcommons.unl.edu/icwdm_usdanwrc/379

This Article is brought to you for free and open access by the U.S. Department of Agriculture: Animal and Plant Health Inspection Service at DigitalCommons@University of Nebraska - Lincoln. It has been accepted for inclusion in USDA National Wildlife Research Center - Staff Publications by an authorized administrator of DigitalCommons@University of Nebraska - Lincoln. 


\section{Authors}

Thomas M. Primus, Dennis J. Kohler, Carol A. Furcolow, Margaret J. Goodall, John J. Johnston, and Peter J. Savarie 


\title{
Determination of Acetaminophen Residues in Whole Body Brown Treesnakes
}

\author{
Thomas M. Primus, ${ }^{1, *}$ Dennis J. Kohler, ${ }^{1}$ Carol A. Furcolow, ${ }^{1}$ \\ Margaret J. Goodall, ${ }^{1}$ John J. Johnston, ${ }^{1}$ and Peter J. Savarie ${ }^{2}$ \\ ${ }^{1}$ Analytical Chemistry Project and ${ }^{2}$ Product Development \\ Section, USDA/APHIS/WS/National Wildlife Research Center, \\ Colorado, USA
}

\begin{abstract}
Acetaminophen was extracted from brown treesnakes (Boiga irregularis) and analyzed by reversed-phase high-performance liquid chromatography (HPLC). Acetaminophen was quantified by UV absorbance at $250 \mathrm{~nm}$. Recoveries were determined by analyzing acetaminophen-fortified blank homogenized tissue. The mean recovery of acetaminophen in whole body brown treesnakes was $87.9 \% \pm 5.9 \%$ and $92.2 \% \pm 5.8 \%$ for the
\end{abstract}

\footnotetext{
*Correspondence: Thomas M. Primus, Analytical Chemistry Project, USDA/APHIS/ WS/National Wildlife Research Center, 4101 LaPorte Ave, Ft. Collins, CO 80521, USA; E-mail: thomas.m.primus@usda.gov.
}

\section{7}


fortification levels of 20 and $2400 \mu \mathrm{g} / \mathrm{g}$, respectively. The method's limit of detection (MLOD) with UV detection was $0.70 \mu \mathrm{g} / \mathrm{g}$.

Key Words: Acetaminophen (CAS\# 114-26-1); Brown treesnake; High-performance liquid chromatography; UV detection; Tissue.

\section{INTRODUCTION}

The brown treesnake (Boiga irregularis) is not indigenous to the island of Guam, but was probably introduced accidentally after the end of World War II. Since then, this snake has been responsible for the extinction of nine species of native forest birds ${ }^{[1,2]}$ and the decline of several lizards species on Guam. ${ }^{[3]}$ The brown treesnake is mildly venomous and poses a health risk to children, ${ }^{[4]}$ causes electrical power outages by climbing on wires ${ }^{[5]}$ and preys on domesticated birds. ${ }^{[6]}$ An integrated control strategy is being developed for these snakes with chemical control being investigated as one possibility. Dermal and oral toxicity experiments were conducted on brown treesnakes with several candidate compounds. ${ }^{[7]}$ Currently, acetaminophen, in a carrion-based delivery system, is being investigated as an oral toxicant for control of brown treesnake populations on $\mathrm{Guam}^{[8]}$ due to its availability, reasonable cost, and the potential for registration under the Federal Insecticide, Fungicide, and Rodenticide Act (FIFRA).

Acetaminophen is an over-the-counter analgesic, antipyretic drug and has no prior history of use as a pesticide. Studies related to its use in clinical research tends to focus on the analysis of plasma and urine, therefore, analytical methods for the determination of acetaminophen in whole bodies, muscle, or liver tissue ${ }^{[9]}$ are rarely published. A method was developed in-house for the determination of acetaminophen in white mice and was used for a study to evaluate acetaminophen stability in mouse baits. ${ }^{[10,11]}$

A rapid and reliable analytical method was needed to determine acetaminophen residues in brown treesnakes to help interpret efficacy experiments, and as a tool to potentially assess secondary hazards. This work reports the development of a validated method for the assay of acetaminophen residues in brown treesnake tissue at concentrations of $20-2400 \mu \mathrm{g} / \mathrm{g}$. The wide range of acetaminophen concentrations was required because some snakes regurgitated the baits shortly after ingestion while other snakes did not. 


\section{EXPERIMENTAL}

\section{Samples}

The samples consisted of whole brown treesnakes (control and treated) from the island of Guam. Control snakes were analyzed to assure the absence of analyte or chromatographic interferences. Control snakes were fortified (see fortification of controls) with known amounts of acetaminophen for method development and quality control samples.

\section{Apparatus}

A Hewlett Packard (Palo Alto, CA) 1090M high-performance liquid chromatography (HPLC) system equipped with a Hewlett-Packard computer workstation was operated at $25^{\circ} \mathrm{C}$ with a Phenomenex Prodigy ODS (Torrance, $\mathrm{CA})$ analytical column $(250 \mathrm{~mm} \times 4.6 \mathrm{~mm}$ i.d.) and a guard column $(15 \mathrm{~mm} \times 4.6 \mathrm{~mm}$ i.d.). The HPLC was equipped with an ultra-violet/visible diode array detector set at $250 \mathrm{~nm}$ to detect acetaminophen. Sample extracts and standards $(25 \mu \mathrm{L})$ were chromatographed with a mobile phase consisting of a 15:85 mixture of methanol:50 mM potassium phosphate, monobasic $(\mathrm{pH}=3.25)$ aqueous solution with a flow rate of $1.0 \mathrm{~mL} / \mathrm{min}$ and a runtime of $20 \mathrm{~min}$. The solvents were filtered through a $0.45 \mu \mathrm{m}$ nylon filter and degassed by sparging with helium.

\section{Reagents}

Liquid chromatography grade acetone (Fischer Scientific, Denver, CO) was used as the extraction solvent. Potassium phosphate, monobasic (99\%) was obtained from Fischer (Denver, CO). Acetaminophen (99\%) was obtained from Chem Service, Inc. (West Chester, PA). A solution consisting of a 20:80 mixture of methanol: $50 \mathrm{mM}$ potassium phosphate, monobasic $(\mathrm{pH}=3.25)$ aqueous solution was used to reconstitute the final extracts and dilute calibration standards.

Concentrated standard solutions were prepared by accurately weighing $10.0 \mathrm{mg}$ of acetaminophen into a $10.00-\mathrm{mL}$ volumetric flask. The acetaminophen was dissolved in methanol, followed by dilution to volume with the same solvent. The concentration of the standard was $\sim 1 \mathrm{mg} / \mathrm{mL}$ $(1000 \mu \mathrm{g} / \mathrm{mL})$. 


\section{Calibration Curve}

Calibration standard solutions for ultra-violet detection ranged from 0.5 to $150 \mu \mathrm{g} / \mathrm{mL}$. All calibration standard solutions were prepared in $10.00-\mathrm{mL}$ volumetric flasks with the methanol: water buffer solution as the diluent.

\section{Extraction of Acetaminophen in Brown Treesnake}

Partially frozen whole brown treesnakes were cut into approximately 2 in. pieces. The pieces were frozen with liquid nitrogen in a stainless steel cylindrical container. The frozen snake was shattered into a powder with a steel piston. Once most of the tissue was powdered, the large unhomogenized pieces of tissue were removed. The powdered tissue was transferred to a separate container and the remaining pieces were refrozen with liquid nitrogen and shattered into powder, and combined with the rest of the powdered sample. ${ }^{[12]}$

For each sample, a 1.00-1.10 g portion of powdered tissue was weighed into a $50-\mathrm{mL}$ glass tube. A $10.0 \mathrm{~mL}$ aliquot of acetone was added from a calibrated volumetric device. Each tube was sealed with a screw cap and vortex mixed. All of the tubes were shaken on a mechanical shaker for $10 \mathrm{~min}$ on the high setting. The samples were then placed in an ultrasonic bath for $30 \mathrm{~min}$, followed by centrifuging for $5 \mathrm{~min}$. A $1.00 \mathrm{~mL}$ aliquot of the resulting extract was transferred to a $15-\mathrm{mL}$ graduated centrifuge tube and the solvent was evaporated by blowing a stream of nitrogen over the solution with the tube in a warm water bath at $60-65^{\circ} \mathrm{C}$. The dry residue was reconstituted by adding $2.00 \mathrm{~mL}$ of the methanol: water buffer solution and vortex mixed. The reconstituted samples were placed in an ultrasonic bath for $10 \mathrm{~min}$ in a glass beaker. A portion of each sample was filtered through a $0.45 \mu \mathrm{m}$ Teflon disk into an amber LC vial, and sealed with a crimp cap. Each standard and sample were analyzed by HPLC.

Operating conditions were adjusted to obtain optimum response and reproducibility. For 15:85 methanol: water with phosphate buffer mobile phase, the retention time of acetaminophen was approximately $12.8 \mathrm{~min}$. At the end of each analysis sequence, a column wash was performed by pumping $80: 20$ water:methanol through the guard and analytical columns for approximately $30 \mathrm{~min}$.

\section{Fortification of Controls}

Acetaminophen fortification standard solutions at 20,000 and $1000 \mu \mathrm{g} / \mathrm{mL}$ in methanol were used for fortifying the control tissue to evaluate analyte 
recovery. Each $1.00 \mathrm{~g}$ portion of control brown treesnake tissue was fortified at 2400 or $20 \mu \mathrm{g} / \mathrm{g}$ with 0.120 or $0.020 \mathrm{~mL}$ aliquots of the 20,000 and $1000 \mu \mathrm{g} / \mathrm{mL}$ fortification standard solutions, respectively. The methanol was allowed to evaporate for $20 \mathrm{~min}$ and the extraction and cleanup procedure was followed as previously described.

\section{RESULTS AND DISCUSSION}

\section{Instrumental Data}

Two sets of calibration standard solutions were prepared ranging in concentrations from 0.50 to $150 \mu \mathrm{g} / \mathrm{mL}$ for UV detection. Each standard solution was injected twice, and a plot was constructed of acetaminophen chromatographic peak area response ( $y$-axis) vs. acetaminophen concentrations ( $x$-axis). A linear regression was performed on the data set. Linearity of chromatographic response was assessed for the chromatography conditions required for this system. In each case, a range of acetaminophen standard solutions at concentrations including the expected acetaminophen concentrations in quality control and field samples were analyzed. In all cases, linear regression analysis of concentration vs. response yielded an $r^{2}$ greater than 0.99. Linear regression analysis of the $\log : \log$ plot of these data yielded a slope that was not significantly different than $1(P>0.05)$. These data indicated that the chromatographic responses for acetaminophen were linear and proportional, which justified the use of single point external standard for quantification of acetaminophen in the sample extracts.

\section{Instrumental and Method Limits of Detection}

Instrument limit of detection (ILOD) was defined as the concentration of acetaminophen in a calibration standard required to generate a signal equal to $3 \times$ the baseline noise (measured peak-to-peak) observed in the blank diluent. The ILOD was estimated from the mean chromatographic peak height of a acetaminophen standard solution $(1.0 \mu \mathrm{g} / \mathrm{mL}$ for $\mathrm{UV})$ and the peak-to-peak noise observed from three reagent blank samples. The ILOD for UV detection was determined to be $0.034 \mu \mathrm{g} / \mathrm{mL}$ for acetaminophen.

Method limit of detection (MLOD) was defined as the concentration of acetaminophen in the sample required to generate a signal equal to $3 \times$ the baseline noise (measured peak-to-peak) observed in the control sample. The MLOD was estimated from the mean chromatographic peak 
height of acetaminophen in seven fortified samples $(20 \mu \mathrm{g} / \mathrm{g}$ for UV) and the peak-to-peak noise observed from seven control samples. The MLOD for UV detection was determined to be $0.72 \mu \mathrm{g} / \mathrm{g}$ for acetaminophen.

\section{Residue in Brown Treesnakes}

The recoveries of acetaminophen from control brown treesnake samples at two fortified levels, assayed for four different sets of samples over a 2 week period, are listed in Table 1 . The recoveries ranged from $72.2 \%$ to $102 \%$ with a mean of $90.1 \%$ and a $\mathrm{CV}$ of $6.2 \%$ for 42 replicates at fortification levels of 20 and $2400 \mu \mathrm{g} / \mathrm{g}$. Chromatograms of a control sample extract (Fig. 1), and extracts from control samples fortified at approximately $2400 \mu \mathrm{g} / \mathrm{g}$ acetaminophen (Fig. 2) and $20 \mu \mathrm{g} / \mathrm{g}$ acetaminophen (Fig. 3) analyzed with field study samples, are shown. As shown from the attached chromatograms, no interferences were observed for UV detection at $250 \mathrm{~nm}$.

The residue results of brown treesnakes from an efficacy study in which the snakes ingested $80 \mathrm{mg}$ acetaminophen fortified baits are shown in Table 2. Samples were homogenized and assayed in duplicate. The method yielded very reproducible results over a wide range of incurred residues, as the mean coefficient of variation for all the samples listed in Table 1 was less than $10 \%$. Incurred residues ranged from $708 \mu \mathrm{g} / \mathrm{g}$ to less than the MLOD. A chromatogram of an actual snake sample extract (Fig. 4) collected during a field study is shown. The snake weighed $88.9 \mathrm{~g}$ with a concentration of $204 \mu \mathrm{g} / \mathrm{g}$ observed in this extract.

Table 1. Fortification levels and percent recoveries for acetaminophen in brown treesnake tissue.

\begin{tabular}{lcc}
\hline & Fortification levels $(\mu \mathrm{g} / \mathrm{g})$ \\
\hline & 20 & 2,400 \\
\hline Replicates & 21 & 21 \\
Mean & 87.9 & 92.2 \\
SD & 5.9 & 5.8 \\
CV & 6.7 & 6.3 \\
\hline
\end{tabular}


ORDER

Acetaminophen Residues in Brown Treesnakes

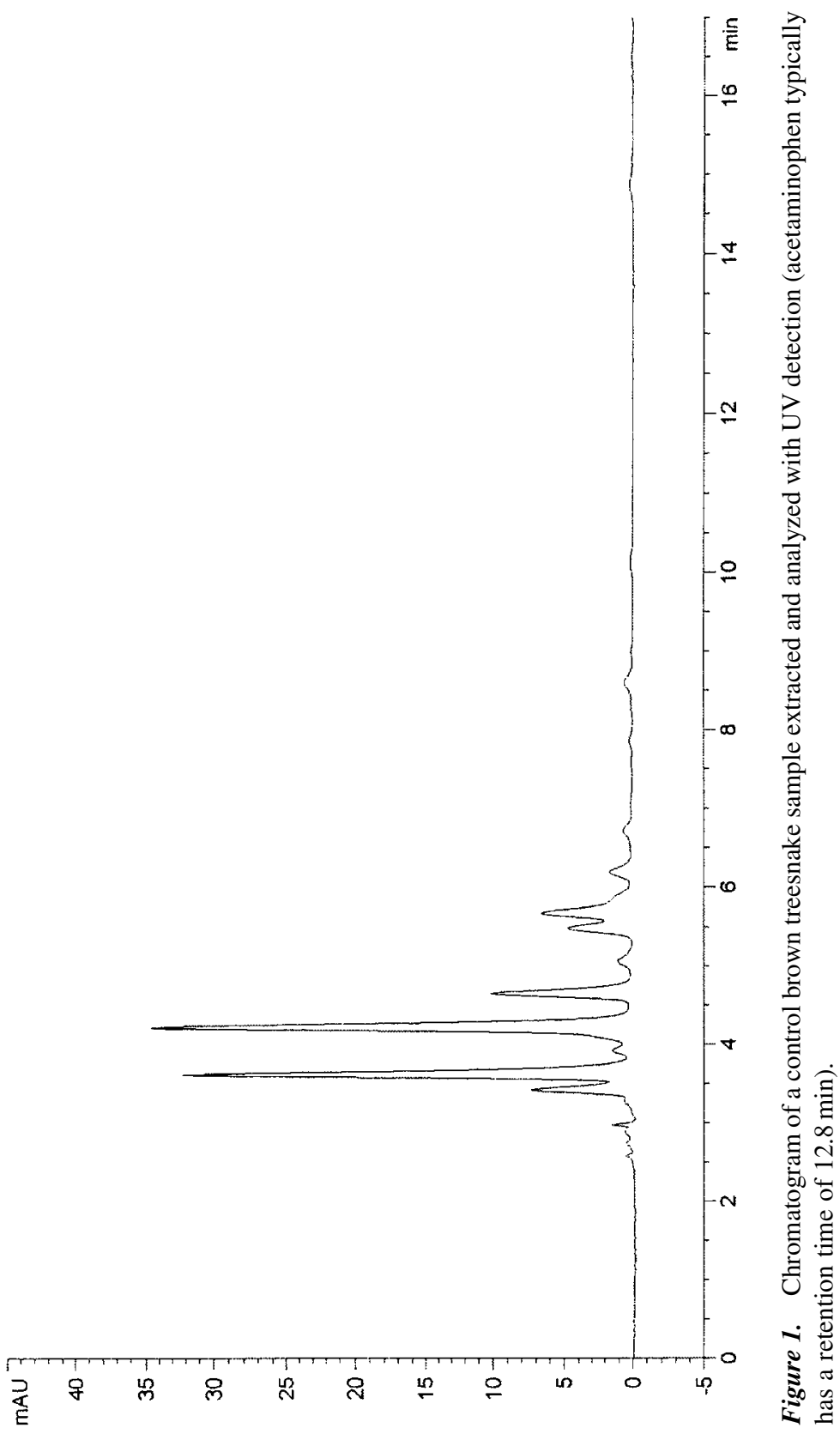




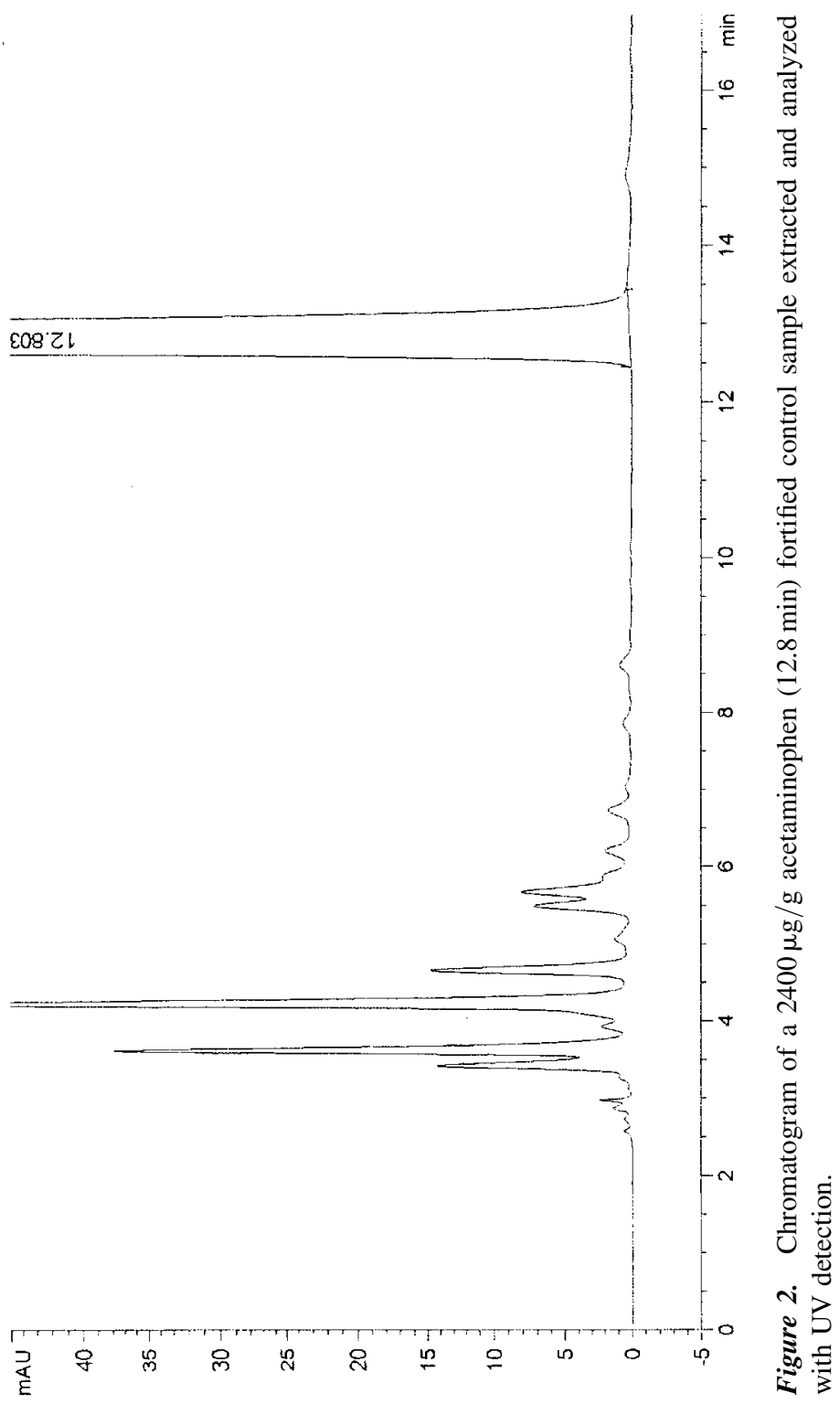


ORDER

Acetaminophen Residues in Brown Treesnakes

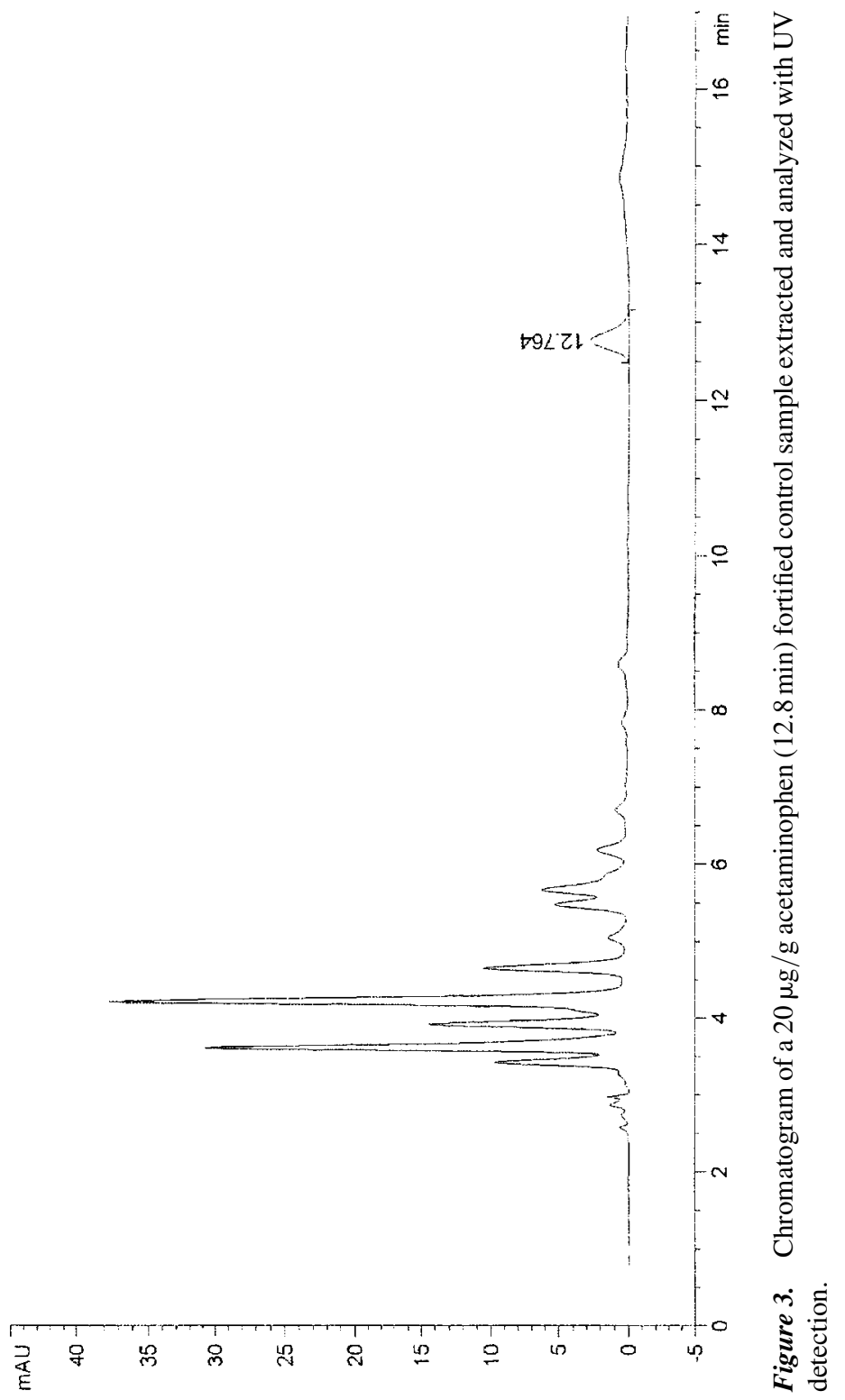


Primus et al.

Table 2. Orally treated brown treesnakes.

\begin{tabular}{|c|c|c|c|c|}
\hline Sample \# & $\begin{array}{l}\text { Description of } \\
\text { treatment }\end{array}$ & $\begin{array}{l}\text { Weight of } \\
\text { snake }(g)\end{array}$ & $\begin{array}{l}\text { Acetaminophen } \\
(\mu \mathrm{g} / \mathrm{g})\end{array}$ & Note \\
\hline 1 & $0 \mathrm{mg}$ - day 0 & 29.9 & $<$ MLOD & \\
\hline 2 & $0 \mathrm{mg}$ - day 0 & 90.6 & $<$ MLOD & \\
\hline 3 & $0 \mathrm{mg}$ - day 0 & 108.4 & $<$ MLOD & \\
\hline 4 & $80 \mathrm{mg}$-day 0 & 52.5 & 7.0 & $\begin{array}{l}\text { Regurgitated } \\
\text { bait }\end{array}$ \\
\hline 5 & $80 \mathrm{mg}$ - day 0 & 56.1 & 3.3 & $\begin{array}{l}\text { Regurgitated } \\
\text { bait }\end{array}$ \\
\hline 6 & $80 \mathrm{mg}$ - day 0 & 79.3 & 505 & \\
\hline 7 & $80 \mathrm{mg}$ - day 0 & 88.4 & 398 & \\
\hline 8 & $80 \mathrm{mg}$ - day 0 & 102.7 & 358 & \\
\hline 9 & $80 \mathrm{mg}$ - day 0 & 139.8 & 151 & \\
\hline 10 & $0 \mathrm{mg}$ - day 1 & 53.0 & $<$ MLOD & \\
\hline 11 & $0 \mathrm{mg}$ - day 1 & 90.5 & $<$ MLOD & \\
\hline 12 & $0 \mathrm{mg}$ - day 1 & 128.8 & $<$ MLOD & \\
\hline 13 & $80 \mathrm{mg}$ - day 1 & 59.9 & 388 & \\
\hline 14 & 80 mg_day 1 & 58.1 & 19.3 & $\begin{array}{l}\text { Regurgitated } \\
\text { bait }\end{array}$ \\
\hline 15 & $80 \mathrm{mg}$ - day 1 & 88.9 & 291 & \\
\hline 16 & $80 \mathrm{mg}$-day 1 & 154.4 & 126 & \\
\hline 17 & $0 \mathrm{mg}$ - day 2 & 55.3 & $<$ MLOD & \\
\hline 18 & $0 \mathrm{mg}$-day 2 & 85.9 & $<$ MLOD & \\
\hline 19 & $0 \mathrm{mg}$ - day 2 & 127.0 & $<$ MLOD & \\
\hline 20 & $80 \mathrm{mg}$ - day 2 & 48.4 & 735 & \\
\hline 21 & $80 \mathrm{mg}$ - day 2 & 25.4 & 648 & \\
\hline 22 & $80 \mathrm{mg}$ - day 2 & 73.6 & 391 & \\
\hline 23 & $80 \mathrm{mg}$ - day 2 & 73.5 & 461 & \\
\hline 24 & $80 \mathrm{mg}$ - day 2 & 78.9 & 16.0 & $\begin{array}{l}\text { Regurgitated } \\
\text { bait }\end{array}$ \\
\hline 25 & $80 \mathrm{mg}$ - day 2 & 110.8 & 246 & \\
\hline 26 & $0 \mathrm{mg}$ - day 3 & 40.2 & $<$ MLOD & \\
\hline 27 & $0 \mathrm{mg}$-day 3 & 27.7 & $<$ MLOD & \\
\hline 28 & $0 \mathrm{mg}$ - day 3 & 75.9 & $<$ MLOD & \\
\hline 29 & 80 mg_day 3 & 20.3 & 16.4 & $\begin{array}{l}\text { Regurgitated } \\
\text { bait }\end{array}$ \\
\hline 30 & $80 \mathrm{mg}$-day 3 & 21.2 & 5.4 & $\begin{array}{l}\text { Regurgitated } \\
\text { bait }\end{array}$ \\
\hline 31 & $80 \mathrm{mg}$-day 3 & 39.8 & 164 & \\
\hline 32 & $80 \mathrm{mg}$ - day 3 & 30.7 & 213 & \\
\hline 33 & $80 \mathrm{mg}$ - day 3 & 35.0 & 24.4 & \\
\hline
\end{tabular}

(continued) 
Table 2. Continued.

\begin{tabular}{lcccc}
\hline Sample \# & $\begin{array}{c}\text { Description of } \\
\text { treatment }\end{array}$ & $\begin{array}{c}\text { Weight of } \\
\text { snake }(\mathrm{g})\end{array}$ & $\begin{array}{c}\text { Acetaminophen } \\
(\mu \mathrm{g} / \mathrm{g})\end{array}$ & Note \\
\hline 34 & $80 \mathrm{mg}$-day 3 & 97.2 & 118 & \\
35 & $0 \mathrm{mg}$-day 4 & 12.4 & 1.4 & \\
36 & $0 \mathrm{mg}$-day 4 & 35.2 & $<$ MLOD & \\
37 & $0 \mathrm{mg}$-day 4 & 46.8 & $<$ MLOD & \\
38 & $80 \mathrm{mg}$-day 4 & 38.7 & 230 & \\
39 & $80 \mathrm{mg}$-day 4 & 17.6 & 344 & Regurgitated \\
40 & $80 \mathrm{mg}$-day 4 & 19.9 & 228 & bait \\
41 & $80 \mathrm{mg}$-day 4 & 29.3 & 9.00 & \\
& & & & 19.5 \\
42 & $80 \mathrm{mg}$-day 4 & 38.5 & 63.7 & \\
43 & $80 \mathrm{mg}$-day 4 & 32.7 & &
\end{tabular}

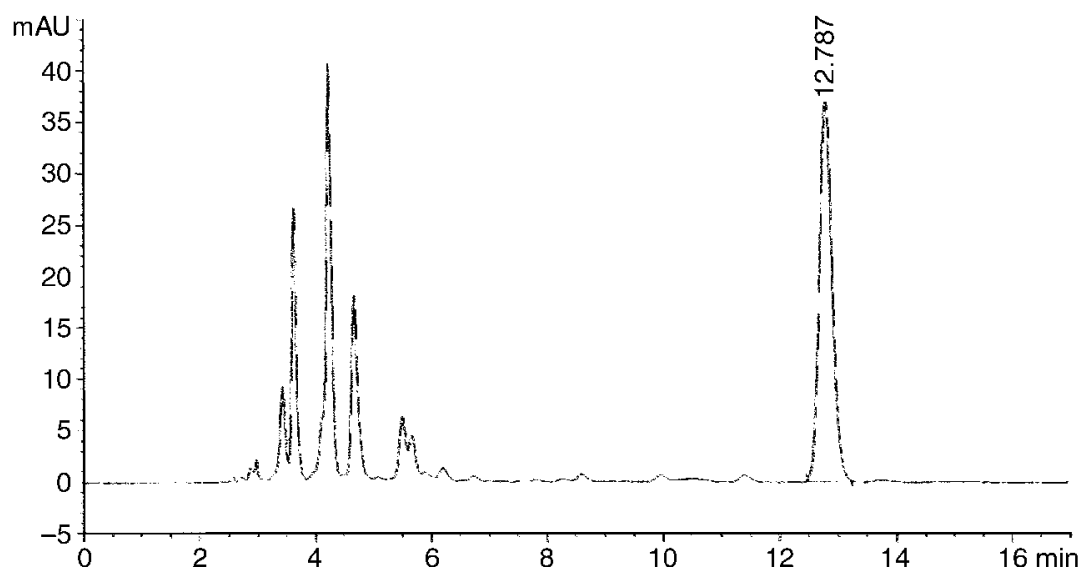

Figure 4. Chromatogram of a brown treesnake carcass collected from a baited trap extracted and analyzed with UV detection. The snake carcass weighed $88.9 \mathrm{~g}$ with an assayed concentration $204 \mu \mathrm{g} / \mathrm{g}$ acetaminophen (12.8 min).

This method was used to support multiple field and laboratory studies conducted on Guam. The resulting residue data are being used to determine nontarget hazards to scavengers and/or predators that might consume acetaminophen poisoned snake carcasses. These hazard assessments play a key role in the development of safe baiting strategies for the control of brown treesnakes on Guam. 


\section{ACKNOWLEDGMENTS}

We are grateful to Rick Bruggers, Assistant Director of the National Wildlife Research Center for managing the NWRC brown treesnake project and the Department of Defense Legacy Fund Project \# 1281, Development of Chemical Control Methods for Brown Treesnake Management for providing funding for this work.

Mention of commercial products is for identification only and does not constitute endorsement by the US Department of Agriculture.

\section{REFERENCES}

1. Savidge, J.A. Extinction of an island forest avifauna by an introduced snake. Ecology 1987, 68, 660-668.

2. Rodda, G.H.; McCoid, M.J.; Fritts, T.H.; Campell III, E.W. Population trends and limiting factors in Boiga irregularis. In Problem Snake Management, The Habu and the Brown Treesnake; Fritts, T.H.; Rodda, G.H.; Sawai, Y.; Cjozzar, D.; Tanaka, H; Eds. Comstock Publishing Associates: Ithaca, NY, 1999; 236-256.

3. Rodda, G.H.; Fritts, T.H. The impact of the introduction of the brown treesnake, Boiga irregularis, on Guam's lizards. J. Herpetol. 1992, 26, $166-174$.

4. Fritts, T.H.; McCoid, M.J.; Haddock, R.L. Risks to infants on Guam from bites of the brown treesnake (Boiga irregularis). Amer. J. Trop. Med. Hyg. 1990, 42, 607-611.

5. Fritts, T.H.; Scott, N.J., Jr.; Savidge, J.A. Activity of the arboreal brown treesnake (Boiga irregularis) on Guam as determined by electrical outages. Snake 1987, 19, 51-58.

6. Fritts, T.H.; McCoid, M.J. Predation by the brown treesnake (Boiga irregularis) on poultry and other domesticated animals on Guam. Snake 1991, 23, 75-80.

7. Savarie, P.J.; York, D.L.; Hurley, J.C.; Volz, S.A. Testing the dermal and oral toxicity of selected chemicals to brown treesnakes. Verte. Pest. Conf. 2000, 19, 139-145.

8. Savarie, P.J.; Shivik, J.A.; White, G.C.; Hurley, J.C.; Clark, L. Use of acetaminophen for large scale control of brown treesnakes. J. Wildl. Manage 2001, 65, 356-365.

9. Pufal, E.; Sykutera, M.; Rochholz, G.; Schütz, H.W.; Sliwka, K.; Kaatsch, H.J. Determination of paracetamol (acetaminophen) in different body fluids and organ samples after solid-phase extraction using HPLC 
and an immunological method. Fresenius J. Anal. Chem. 2000, 367, 596-599.

10. Primus, T.M.; Kohler, D.J. Storage and Stability of Acetaminophen in Fortified Mouse Baits Under Field and Freezer Conditions; National Wildlife Research Center: Unpublished Report, 2001; 13.

11. Johnston, J.J.; Savarie, P.J.; Primus, T.M.; Eisemann, J.D.; Hurley, J.C.; Kohler, D.J. Risk assessment of an acetaminophen baiting program for chemical control of brown treesnakes on Guam: evaluation of baits, snake residues, and potential primary and secondary hazards. Environ. Sci. Technol. 2002, 36, 3827-3833.

12. Sterner, R.T.; Mauldin, R.E. Regressors of whole-carcass zinc phosphide residues in voles: indirect evidence of low hazards to predators/ scavengers. Arch. Environ. Contam. Toxicol. 1995, 28, 519-523.

Received August 1, 2003

Accepted October 23, 2003

Manuscript 6205 
Copyright of Journal of Liquid Chromatography \& Related Technologies is the property of Marcel Dekker Inc. and its content may not be copied or emailed to multiple sites or posted to a listserv without the copyright holder's express written permission. However, users may print, download, or email articles for individual use. 